\title{
Reimagining Islamic Ethics in Contemporary International Relations
}

\author{
Ahmad Badri Abdullah*
}

The deplorable plight of Rohingya Muslim boat refugees who have been refused entry by their neighboring Muslim countries was a disheartening episode for the ummah. The subsequent involvement of the Turkish government in dispatching ships of the Turkish Armed Forces to rescue the refugees has reopened the discourse on the necessity for a confederation of Muslim nation-states acting in concert within the global context as an operative framework of Islamic ethics in international relations. The episode invites Muslims to rethink the role of their own religious tradition in providing relevant ethical guidelines for international affairs that simultaneously address the reality of the modern nation-state.

Islam facilitates a systematic study of ethics through both the authority of the Qur'an and Sunnah as well as through independent judgment and reasoning (ijtiha $\bar{a}$ ). The emphasis on Islam's ethical tradition does justice to the central concerns of Islam which are imperatively spiritual, as well as to its elements which have immensely influenced the secular realms that are beyond the limits of the sacred and the spiritual. To a great degree, Islam continues to influence the domestic and foreign policies of Muslim-majority countries across the globe. Therefore the relevance of Islam to the modern international system can never be overstated. However ethics as applied to international relations is unfortunately a neglected field in contemporary Muslim scholarship.

The earliest account on international relations by a Muslim scholar was provided by al-Shaybani (d. $189 \mathrm{AH} / 804 \mathrm{CE}$ ) via his theory of siyār (laws of nations) which prescribes measures to manage the relations between Muslim countries as well as their relations with non-Muslim countries. The theory divides the world into three domains, namely the domain of peace (dār al-Islām),

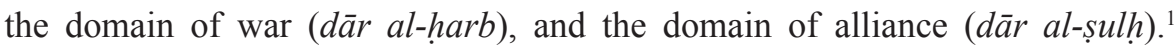
Nonetheless the post-World War international socio-political realities demand a revision to this classical scheme. Thus, for prominent contemporary scholars, war is no longer the normal state of affairs between Muslims and non-Muslims. A nation in which Muslims residents enjoy a high degree of religious freedom cannot be deemed an abode of war. Accordingly, the scholars propose that secular democratic nations which have embassies or enjoy diplomatic relations with Muslim countries fall within the realm of the abode of covenant (dār al- 'ahd) or the abode of invitation to Islam ( $d \bar{a} r$ al-da' $w a h)$. 
Beyond the classical theory of siya $r$, few innovative ventures have been seen to date. Instead, faced with the challenge of a radically new international order unleashed by European imperialism, Muslim thinkers apologetically proposed compatibility of Western practices and institutions with various Qur'anic verses and prophetic hadiths rather than formulate novel Islamic ethical theories of international relations. Such theories need to be articulated to realize the Sharì'ah's aim to provide meaningful guidance to Muslim collective life, towards a just world order as enshrined in the Qur'an. Moreover Muslims and the third world states are more amenable to abiding by their own ethical principles rather than those which are foreign to them.

A close reading of the Qur' an suggests that it invests primarily in the one global Muslim community (ummah) and condemns moral attributions along linguistic, tribal, or ethnic lines. The collective community of Muslims has been endowed with a high standing by virtue of their humanity and moral commitment, not by their affiliation to any particular human group, be it racial, ethnic, or national. Therefore, the modern concept of nation-state is alien to the Islamic outlook of international relations as argued by Muhammad Iqbal:

"Tribal or national organisations on the lines of race or territory are only temporary phases in the unfoldment and upbringing of collective life, and inasmuch as I have no quarrel with them; but I condemn them in the strongest possible terms when they are regarded as the ultimate expression of the life of mankind." ${ }^{2}$

As an elementary example for this discussion, Sohail Hashmi argued that humanitarian intervention deconstructs the modern concept of the nation-state. Humanitarian crises throughout the Muslim world created contingencies which demand for principles of intervention to be duly considered. An Islamic approach to humanitarian intervention is significant for a number of reasons. Among others, international norms of humanitarian intervention have yet to be accepted across all nations and cultures, especially in the third world countries where any form of intervention is regarded as the lingering legacy of Western imperialism. It is imperative therefore that the very concept of humanitarian intervention needs to be based on a universal and cross-cultural consensus. Thus, Hashmi argued, since the enforcement of justice in Islam is elaborated through the concept of jihād, the ethics of humanitarian intervention must now be regarded as part and parcel of the general conception of contemporary jihād.

Two types of humanitarian interventions are noticeably envisaged in the Qur'an, namely intervention on behalf of oppressed Muslim minorities, and intervention in a conflict between Muslims. In the former case, the Qur'an delineates two courses of actions namely the physical removal of the Muslims 
from the oppressor's territory and a collective response of the Muslim community to reclaim the right of the oppressed. ${ }^{3}$ This is definitely relevant to the abovementioned case of the Rohingya refugees who fled their country due to the oppressive policies of the Myanmar regime. In the latter situation, the operative Qur'anic verse suggests two consecutive steps. The first step is to seek reconciliation between the conflicting parties and the second step is to launch a collective intervention on behalf of the aggrieved party due to its unacceptable means to achieve its end. ${ }^{4}$

In spite of that, there is a debate on whether Muslims may cooperate with non-Muslims in collective intervention against an oppressive Muslim regime. On one reading, the Qur'an seems to prohibit Muslims from taking unbelievers as 'friends', 'allies', or 'protector' and this lay the basis for the rulings on rebellions (ahkām al-bughāt) which prohibit the taking of non-Muslim allies to deal with Muslim rebels, especially if the military control is in the hands of non-Muslims.

However, the Qur'an also envisages a more dynamic moral and political cooperation whereby humanity at large needs to positively contribute to the pursuit of a just global community:

"To each among you have We prescribed law and an open way. If God has so

willed, He could have made you a single community, but His aim is to test you in what He has given you. So strive as in a race in all the virtues." ${ }^{5}$

Moreover, the verse that warns Muslims from taking non-Muslims as associates need to be read together with verses that elaborate such ruling to be exercised on those who are clearly hostile to Muslims and to Islam itself. ${ }^{6}$

To be clear, the above elucidation of Islamic ethical guidelines in international affairs appears to oversimplify the complexity of contemporary global scenario in which geo-economic and geopolitical powers constantly shift between multiple actors. However, at the very least these ethical principles should be an eye-opener for Muslims to reimagine the pivotal role that their intellectual tradition can play in offering an alternative outlook on the relations between Muslim nation-statesan outlook that places the collective community (ummah) at its core. It might also pave the way for Muslims to significantly contribute to the establishment of a just global order from the standpoint of their own religious and ethical values.

\section{Notes}

* Ahmad Badri bin Abdullah is Research Fellow at IAIS Malaysia (Email: badri@ iais.org.my).

1. M. Khaduri, The Islamic Law of Nations: Shaybani's Siyār, (Baltimore: The Johns Hopkins University Press, 1966), viii. 
2. Quoted by Perveen Feroze Hassan, The Political Philosophy of Iqbal, (Lahore: Publisher United Ltd., 1970), 126.

3. Q. al-Nisā' (4): $97 \& 75$.

4. Q. al-Hujurāt (49): 9.

5. Q. al-M̄̄'idah (5): 51.

6. Q. al-Mumtahanah (60): 9.

\section{References}

Abdulhamid Abu Sulayman, Towards an Islamic Theory of International Relations (Herndon, VA: International Institute of Islamic Thought, 1993)

Mohamad Abdalla, "Sacred Law In Secular Land: To What Extend Should Shari'a Law be Followed in Australia?", Griffith Law Review, v. 21 no.3 (2012)

Mohammed A. Muqtader Khan, "Islam as an Ethical Tradition of International Relations", Islam and Christian-Muslim Relations, v. 8 no.2 (1997)

Sohail H. Hashmi, "Toward an Islamic Ethics of International Relations: A Research Agenda", The American Journal of Islamic Social Sciences, v.10 no.1 (1993)

Sohail H. Hashmi, "Is There an Islamic Ethic of Humanitarian Intervention?", Ethics and International Affairs, v. 7 (1993) 